NASA/TM-2005-213348

\title{
Multi-Kilowatt Power Module for High-Power Hall Thrusters
}

Luis R. Piñero

Glenn Research Center, Cleveland, Ohio

Glen E. Bowers

Akima Corporation, Fairview Park, Ohio 
Since its founding, NASA has been dedicated to the advancement of aeronautics and space science. The NASA Scientific and Technical Information (STI) Program Office plays a key part in helping NASA maintain this important role.

The NASA STI Program Office is operated by Langley Research Center, the Lead Center for NASA's scientific and technical information. The NASA STI Program Office provides access to the NASA STI Database, the largest collection of aeronautical and space science STI in the world. The Program Office is also NASA's institutional mechanism for disseminating the results of its research and development activities. These results are published by NASA in the NASA STI Report Series, which includes the following report types:

- TECHNICAL PUBLICATION. Reports of completed research or a major significant phase of research that present the results of NASA programs and include extensive data or theoretical analysis. Includes compilations of significant scientific and technical data and information deemed to be of continuing reference value. NASA's counterpart of peerreviewed formal professional papers but has less stringent limitations on manuscript length and extent of graphic presentations.

- TECHNICAL MEMORANDUM. Scientific and technical findings that are preliminary or of specialized interest, e.g., quick release reports, working papers, and bibliographies that contain minimal annotation. Does not contain extensive analysis.

- CONTRACTOR REPORT. Scientific and technical findings by NASA-sponsored contractors and grantees.
- CONFERENCE PUBLICATION. Collected papers from scientific and technical conferences, symposia, seminars, or other meetings sponsored or cosponsored by NASA.

- SPECIAL PUBLICATION. Scientific, technical, or historical information from NASA programs, projects, and missions, often concerned with subjects having substantial public interest.

- TECHNICAL TRANSLATION. Englishlanguage translations of foreign scientific and technical material pertinent to NASA's mission.

Specialized services that complement the STI Program Office's diverse offerings include creating custom thesauri, building customized databases, organizing and publishing research results ... even providing videos.

For more information about the NASA STI Program Office, see the following:

- Access the NASA STI Program Home Page at http://www.sti.nasa.gov

- E-mail your question via the Internet to help@sti.nasa.gov

- Fax your question to the NASA Access Help Desk at 301-621-0134

- Telephone the NASA Access Help Desk at 301-621-0390

- Write to:

NASA Access Help Desk

NASA Center for AeroSpace Information 7121 Standard Drive

Hanover, MD 21076 
NASA/TM-2005-213348

Multi-Kilowatt Power Module for High-Power Hall Thrusters

Luis R. Piñero

Glenn Research Center, Cleveland, Ohio

Glen E. Bowers

Akima Corporation, Fairview Park, Ohio

Prepared for the

40th Joint Propulsion Conference and Exhibit

cosponsored by the AIAA, ASME, SAE, and ASEE

Fort Lauderdale, Florida, July 11-14, 2004

National Aeronautics and

Space Administration

Glenn Research Center 
Available from

NASA Center for Aerospace Information 7121 Standard Drive

Hanover, MD 21076
National Technical Information Service 5285 Port Royal Road Springfield, VA 22100

Available electronically at http://gltrs.grc.nasa.gov 


\title{
Multi-Kilowatt Power Module for High-Power Hall Thrusters
}

\author{
Luis R. Piñero \\ National Aeronautics and Space Administration \\ Glenn Research Center \\ Cleveland, Ohio 44135 \\ Glen E. Bowers \\ Akima Corporation \\ Fairview Park, Ohio 44126
}

\begin{abstract}
Future NASA missions will require high-performance electric propulsion systems. Hall thrusters are being developed at NASA Glenn for high-power, high-specific impulse operation. These thrusters operate at power levels up to $50 \mathrm{~kW}$ of power and discharge voltages in excess of $600 \mathrm{~V}$. A parallel effort is being conducted to develop power electronics for these thrusters that push the technology beyond the $5 \mathrm{~kW}$ state-of-the-art power level. A $10 \mathrm{~kW}$ power module was designed to produce an output of $500 \mathrm{~V}$ and $20 \mathrm{~A}$ from a nominal $100 \mathrm{~V}$ input. Resistive load tests revealed efficiencies in excess of 96 percent. Load current share and phase synchronization circuits were designed and tested that will allow connecting multiple modules in parallel to process higher power.
\end{abstract}

\section{Introduction}

$\mathrm{H}$ igh-power electric propulsion (EP) has been identified as enabling for applications including human Mars missions. ${ }^{1}$ Using a hybrid transportation mission strategy, including EP, cryogenics and aerobraking, the power requirement for the EP system is reduced to 0.5 to $1.0 \mathrm{MWe}$ compared to all electric architectures. A possible implementation of this concept uses an array of $50 \mathrm{~kW}$-class Hall effect thrusters (HET) like the NASA$457 \mathrm{M}^{2}$

Direct-drive approaches using solar arrays or thermo-mechanical systems, that could reduce mass and improve efficiency of power processing units (PPUs), have been demonstrated. ${ }^{3-7}$ However, these systems have several shortcomings including high voltage arcing, lack of regulation and plasma interactions between the HET and solar arrays. For applications were these problems can not be surmounted traditional PPUs with DC-DC converters are required.

PPUs for high power systems challenge current technology. High voltages and currents require special attention so that undesirable power losses and parasitic transients are not created. For high power applications, power can be processed in smaller fractions to reduce voltage and current magnitudes and allow the use of more efficient semiconductors. These power modules can be used as building blocks by connecting them in series or parallel to produce the desired voltages and currents.

Recently NASA Glenn Research Center (NASA GRC) developed a $1 \mathrm{~kW}$ power module for Hall thrusters, shown in Figure $1{ }^{8}$ It consisted of a phase-shifted full-bridge converter operating at a switching frequency of 50 $\mathrm{kHz}$. The module, operated with an input voltage of $100 \pm 20 \mathrm{~V}_{\mathrm{DC}}$, generated a nominal output of $300 \mathrm{~V}_{\mathrm{DC}}$. This module, integrated with a NASA-120Mv2 HET, demonstrated efficiencies in excess of 96 percent. The total component weight of this unit, including printed circuit boards, was $0.765 \mathrm{~kg}$. The reason for developing this module was to create a test bed to evaluate circuits, concepts and designs that could be applied to a higher power module design. 


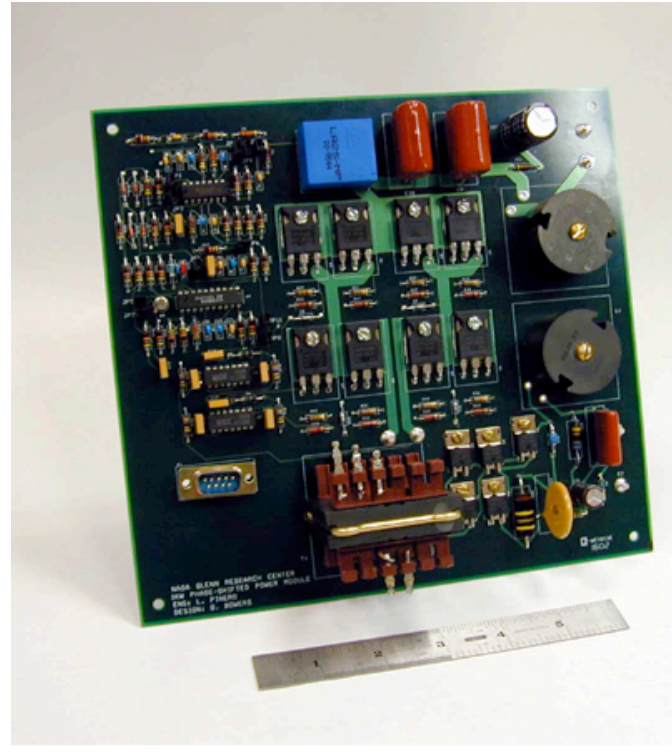

Figure 1. 1kW breadboard power module
The $1 \mathrm{~kW}$ power module was not designed with circuitry to operate multiple modules in a parallel configuration. During this investigation, a load current share circuit was designed and implemented to force the output current to evenly divide between modules. Three 1 $\mathrm{kW}$ modules were connected in an arrangement with both inputs and outputs in parallel to increase current output. In addition, this parallel arrangement enabled the use of a phase-synchronization or phase-staggering circuit that shifted the switching phases of the modules reducing input and output ripples. Three $1 \mathrm{~kW}$ modules including these additional functions were used to assemble a $3 \mathrm{~kW}$ discharge power supply. This unit was successfully integrated with the NASA-120Mv2 HET.

All power and control design concepts implemented in the $1 \mathrm{~kW}$ module were then used to develop a multi-kilowatt power module. A power level of $10 \mathrm{~kW}$ was selected because of semiconductor parts and magnetic cores availability. This paper describes the design of the $10 \mathrm{~kW}$ power module and the $3 \mathrm{~kW}$ parallel architecture discharge supply and the results of resistive load and integration test with a HET.

\section{Thruster Interface and PPU Specifications}

Figure 2 shows a typical block diagram of a HET PPU that includes five power supplies: the discharge, inner and outer magnet, cathode keeper and heater supplies. The largest converter is the discharge supply which processes up to 95 percent of the power into the thruster providing high voltage for accelerating ions by driving a nonlinear, dynamic plasma load that can exhibit large current oscillation and negative resistance characteristics. For these reasons, the design of an optimized discharge supply is paramount to the development of a highly efficient and reliable HET PPU.

The nominal input voltage selected for the $10 \mathrm{~kW}$ power module was $100 \mathrm{~V}$. This voltage is compatible with existing high-power solar-based power systems. ${ }^{9}$ In the case of nuclearbased thermo-mechanical power systems, AC bus voltage magnitude is determined by the alternator design. A trade study would be required to determine if a $100 \mathrm{~V}$ bus is advantageous for a specific application depending on total power level and spacecraft size. ${ }^{10}$ From a PPU perspective, this voltage is advantageous because it allows using of low voltage metal oxide semiconductor field effect transistors (MOSFET) that have low on-resistance and can potentially yield higher efficiency. This is because the on-resistance of power MOSFETs increases rapidly with the voltage handling capability making it difficult to design high efficiency, high voltage converters. This effect is more important for applications with high radiation environments because radiation hardened MOSFETs have even higher on-resistance than standard parts. An output voltage of $500 \mathrm{~V}$ was chosen because HETs like the NASA-457M and the NASA-173M are designed to operate at higher specific impulse requiring higher discharge voltages. $^{2,11-12}$

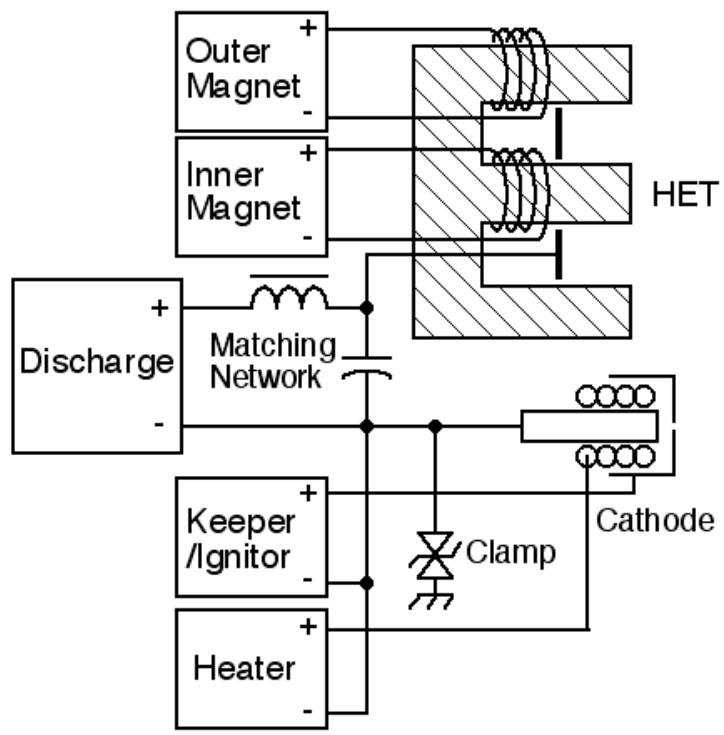

Figure 2. Block Diagram of typical Hall thruster electrical connections

\section{Multi-kilowatt Power Module}

\section{A. Design}

Inefficiencies in high-frequency DC-DC converters are due to conduction and switching losses on power semiconductors, such as MOSFETs and rectifier diodes, and core losses on the magnetic components such as the 
power transformer and filter inductors. Conduction losses are affected by component equivalent resistances and current levels in the module. These can be minimized by using high-performance semiconductors or paralleling parts. Switching losses are caused by turning on and off transistors and rectifier diodes. These losses can be minimized by decreasing switching speed or implementing zero-voltage switching techniques like those used in resonant and pseudo-resonant converters. Regardless of the approach implemented, switching losses are proportional to the switching frequency. ${ }^{13}$ Core losses, which are particular for each core material, are also proportional to the switching frequency and the magnetic flux density in the magnetic core. The design of the 10 $\mathrm{kW}$ power module attempted to minimize these losses to obtain maximum efficiency with a minimum parts count.

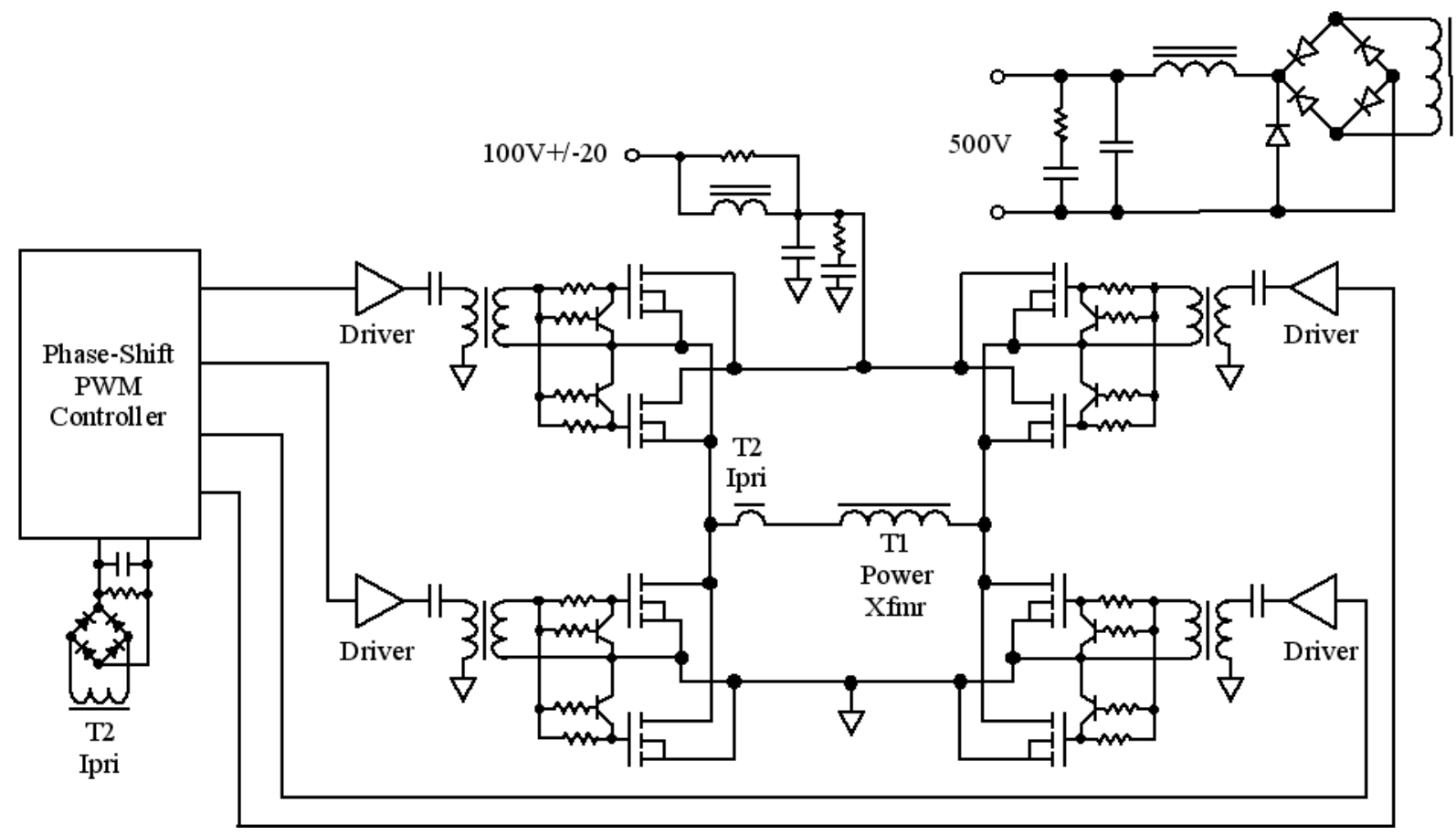

Figure 3. Simplified schematic of $10 \mathrm{~kW}$ power module

The topology used for the $10 \mathrm{~kW}$ module was a phase-shifted full-bridge converter. A simplified circuit schematic is shown in Figure 3. Three significant design changes had to be implemented relative to the $1 \mathrm{~kW}$ design because of the higher power level on this application. First, the switching frequency was decreased from $50 \mathrm{kHz}$ to $20 \mathrm{kHz}$ to reduce switching losses. Second, the power stage that routes input current through the MOSFETs and the transformer was designed to minimize interconnections, current path length and loop inductance. These can introduce parasitic elements to the power circuit resulting in transients detrimental to the performance of a converter. Snubbers are then required to damp these transients at the cost of further power losses. The power stage also included larger heat sinks for improved heat rejection. Third, the gate drive circuit design was changed from a charge-pump based circuit to a transformer-isolated design with high current drivers. This was implemented because the larger gate capacitance in high power transistors requires high current for fast and efficient switching. The bipolar drive from the transformer-isolated design improves turn-off characteristics. In addition, a "Miller killer" circuit, using a bipolar junction transistor, was added to minimize the effect of the Miller capacitance on the MOSFETs and further increase turn-off speed.

Other changes were made to improve efficiency. Two high-power MOSFETs, in an SOT-227 package and with very low on-resistance, were used on each leg of the bridge converter. Also, high-voltage, high-current, ultra-fast, soft-recovery diodes, in a TO-247 packages, were used for the output rectifier. These allowed the use of one single bridge rectification output stage, which minimizes losses and simplifying transformer design. Last, a new high power transformer was assembled by stacking two large ferrite C-cores. The windings utilized an interleaved design, a minimum number of layers and Litz wire to minimize leakage inductance and proximity and skin effects.

As in the $1 \mathrm{~kW}$ module design, phase-shifted, peak-current-mode, pulse-width-modulation (PWM) control was implemented using a commercially available integrated circuit (IC). This device included all the necessary 
functions including the four phase-shifted gate drives, current limit and soft-start. Integrating this IC into the design resulted in a significant part count reduction. The component weight of the $10 \mathrm{~kW}$ power module is $6.2 \mathrm{~kg}$ without including heat sinks or mounting hardware. A photograph of the breadboard is shown in Figure 4.

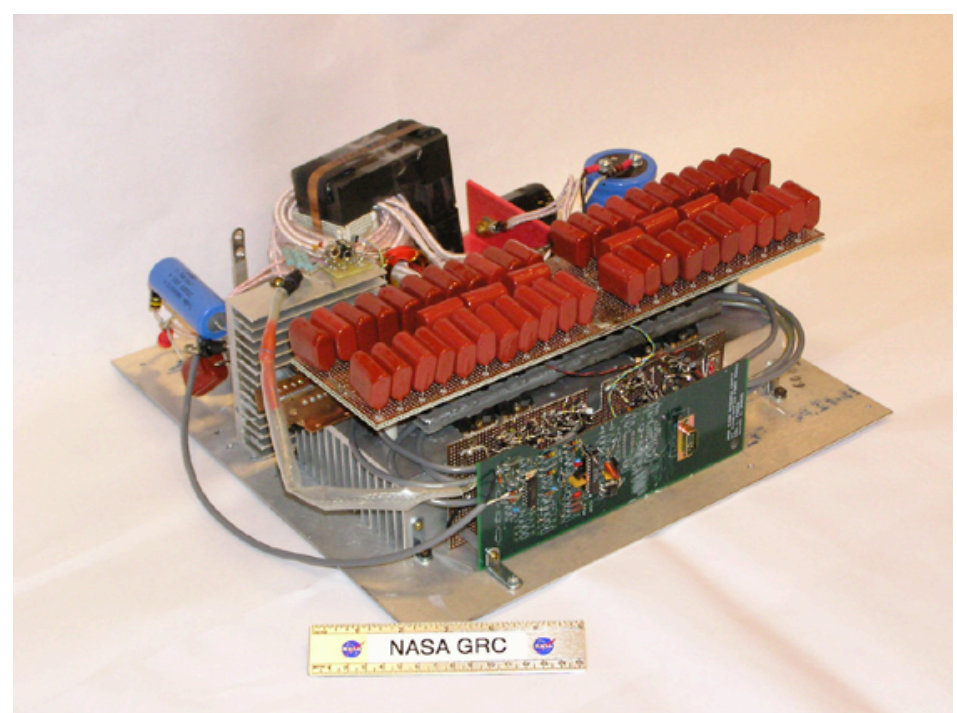

Figure 4. Multi-kilowatt breadboard power module

\section{B. Resistive Load Test}

The performance of the multi-kilowatt power module was tested using a resistive load. Testing included verification of input and output characteristics like voltage, current, ripple and efficiency. Figure 5 shows a graph of total electrical efficiency as a function of output power for various voltages. Efficiencies greater than 96 percent were obtained through a wide range of output powers. These data include housekeeping power. Efficiency measurements were taken after the breadboard module reached thermal equilibrium. These efficiencies were attributed to the soft-switching characteristics of the phase-shift bridge converter, fast gate drive circuits and low parasitics losses inherent in the design.

\section{A. Load Current Sharing Circuit}

\section{Modular Architectures}

Modular architectures provide many advantages including scalability and redundancy due to the ease in adding power modules in parallel or series combinations. A modular architecture also simplifies thermal management as heat dissipation can be distributed throughout the modules. When voltage regulated power supplies are connected in parallel it is necessary to force them to share the output current supplied to the load. If a load share function is not utilized, variations in the modules can introduce large differences in the effective duty cycle of the power converter that can lead to uneven sharing of the load current limiting the maximum output current.

There are passive and active methods of implementing the load current share function. Passive methods that rely on the output impedance of the power converters are simple but can be inaccurate and difficult to implement because they require small component tolerances and circuit parasitics. Active methods yield superior performance and accuracy in exchange for a small amount of additional complexity and circuitry. The most basic way of implementing active load current sharing is a master-slave configuration in which a master module senses its output current and forces the slave modules to output the same amount of current. The disadvantage of this method is that the system is

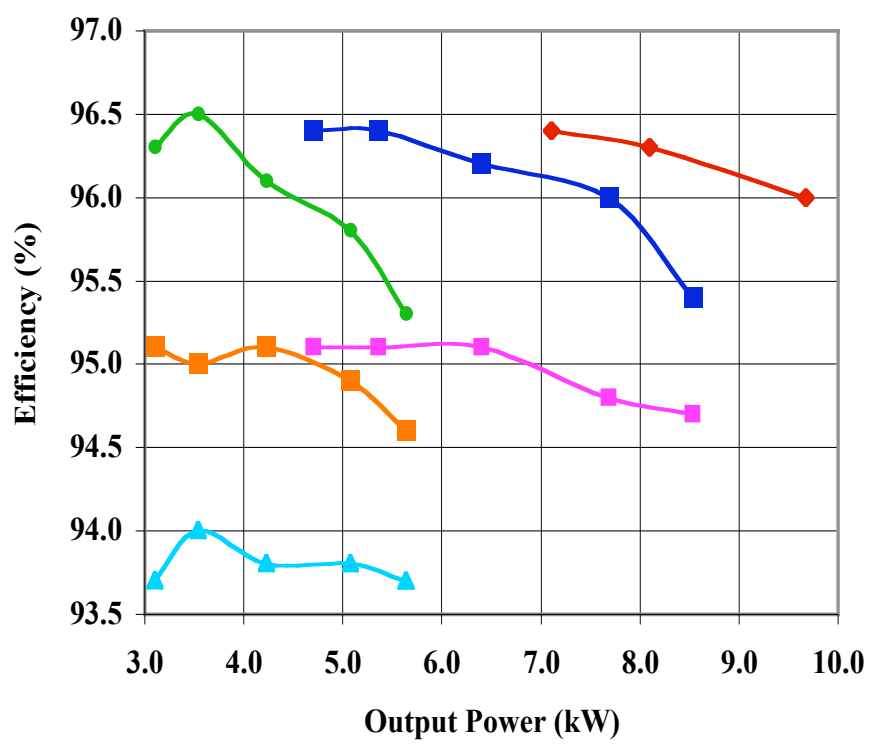

$$
\begin{aligned}
& \longrightarrow 600 \text { Vout } / 120 \text { Vin }-500 \text { Vout } / 120 \text { Vin } \\
& --400 \text { Vout } / 120 \text { Vin } \rightarrow-500 \text { Vout } / 100 \text { Vin } \\
& --400 \text { Vout } / 100 \text { Vin } \rightarrow-400 \text { Vout } / 80 \text { Vin }
\end{aligned}
$$

Figure 5. Multi-kilowatt power module efficiency 


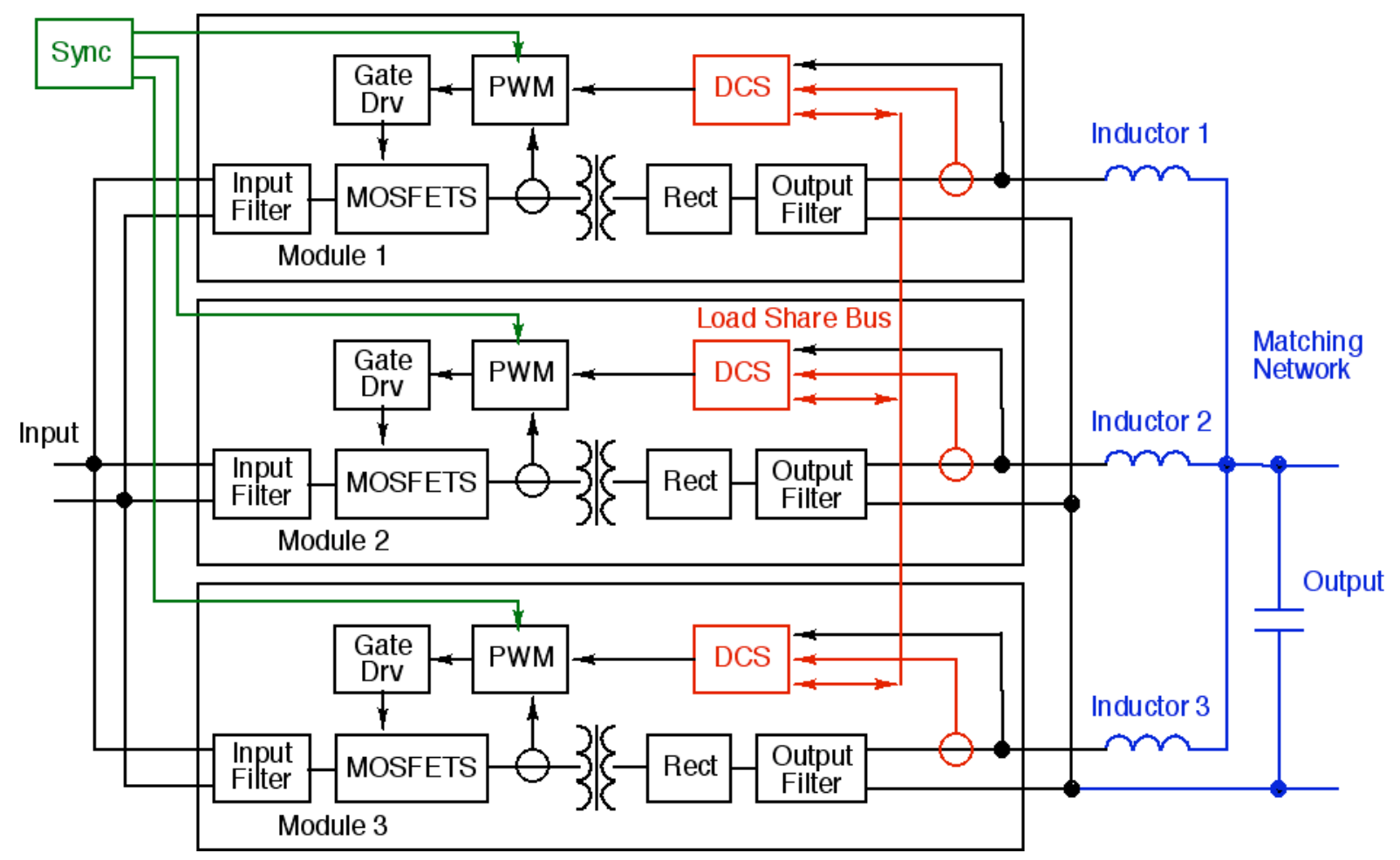

Figure 6. Parallel module architecture block diagram

not tolerant to master module faults. In other methods, the output currents of the modules are compared to the average current, on a common "load share bus", and used to control the input to the error amplifiers of each module. This allows any of the modules to take control of the load share bus and act as a master. If that module fails, it can be disconnected and another module will take over the bus. This technique is called democratic current sharing (DCS) and was implemented in this design using a commercially available DCS controller. ${ }^{14}$

Three $1 \mathrm{~kW}$ modules were assembled and connected in parallel with a DCS circuit. A block diagram of the circuit configuration is shown in Figure 6. This $3 \mathrm{~kW}$ discharge supply was then tested using resistive load to verify load sharing performance under steady state and turn-on conditions. This is particularly important for HET PPUs, because large current transients are possible as the main discharge is initiated in the thruster.

Figure 7, shows a graph of the output currents from each individual module when operating into a fixed resistive load under

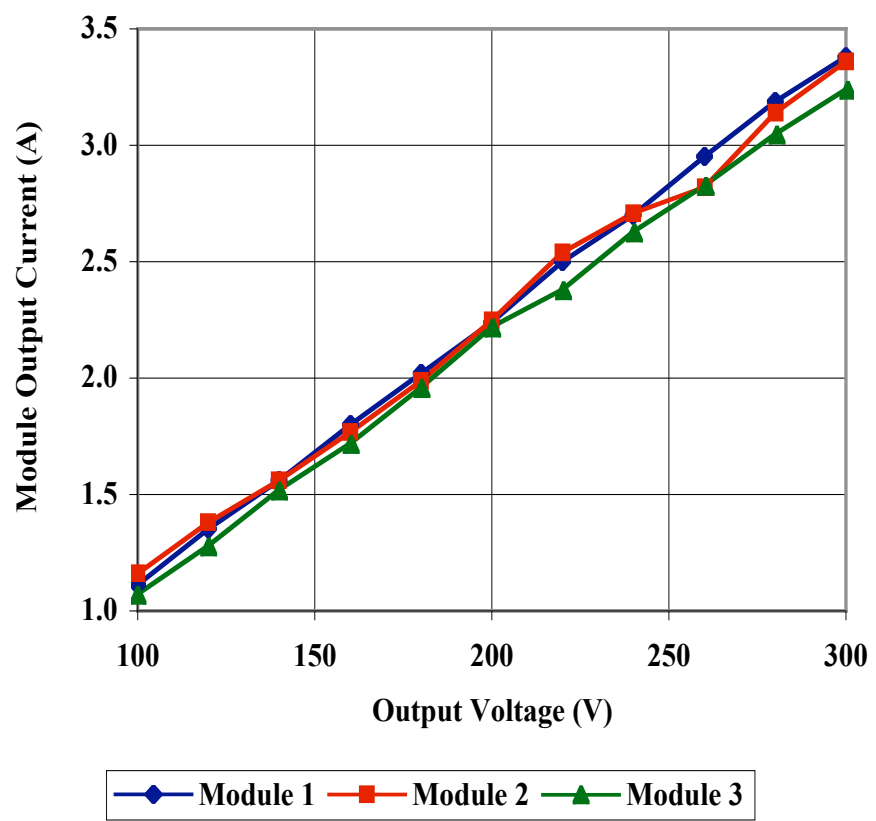

Figure 7. Load current share performance of three $1 \mathrm{~kW}$ modules

nominal conditions of $100 \mathrm{~V}$ input and $300 \mathrm{~V}$ output. Notice that the currents track each other very closely with a variation of no more than 4.2 percent. Similar results were obtained for other load and input conditions. The results of the turn-on test are shown in Figure 8. Figure 8a shows the individual module currents and the output voltage 
ripple for an operating condition of $100 \mathrm{~V}$ input and a $300 \mathrm{~V}$ and $7.56 \mathrm{~A}$ output. The individual modules output currents were 2.54, 2.57 and 2.45 A. Small oscillations can be detected in the current from interaction between the modules. Figure $8 \mathrm{~b}$ shows the same traces taken during a turn-on. Notice that current sharing was maintained even during transient operation. This test was repeated over the entire input and output voltage ranges without significant changes in performance.

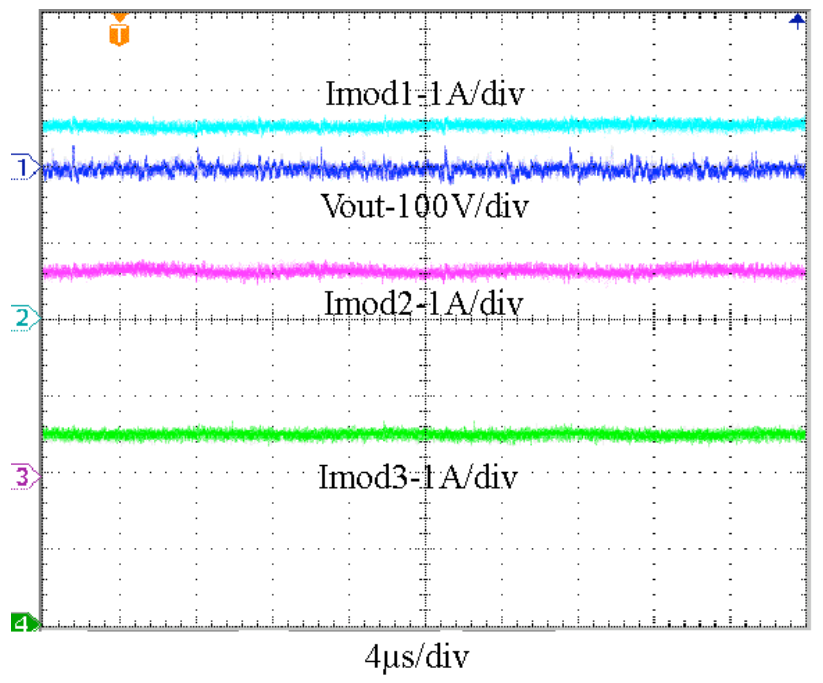

(a)

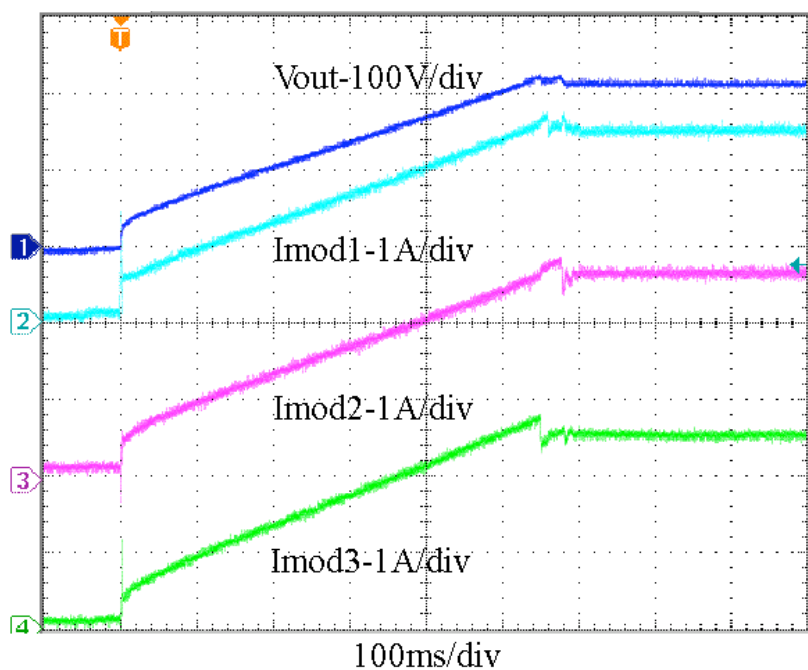

(b)

Figure 8. Waveforms of $3 \mathrm{~kW}$ power supply resistive load testing showing individual module currents during (a) steady state and (b) turn-on conditions

\section{B. Phase Staggering Circuit}

When power modules in a modular architecture are synchronized they draw power from the input bus at exactly the same time causing high ripple currents on both input and output filters. These high input currents require larger filter inductors and capacitors to meet ripple specifications and minimize conducted emissions. Larger filters result in additional PPU mass. If the timing of the modules can be distributed or staggered throughout the switching period, peak input currents can be reduced because each module draws current at different times. The performance of the power supply is not affected.

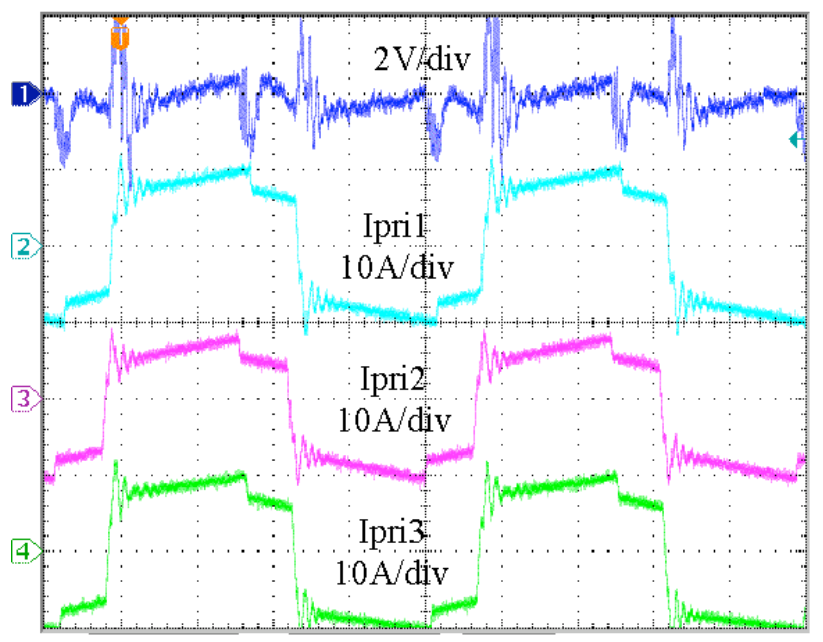

$4 \mu \mathrm{s} / \mathrm{div}$

(a)

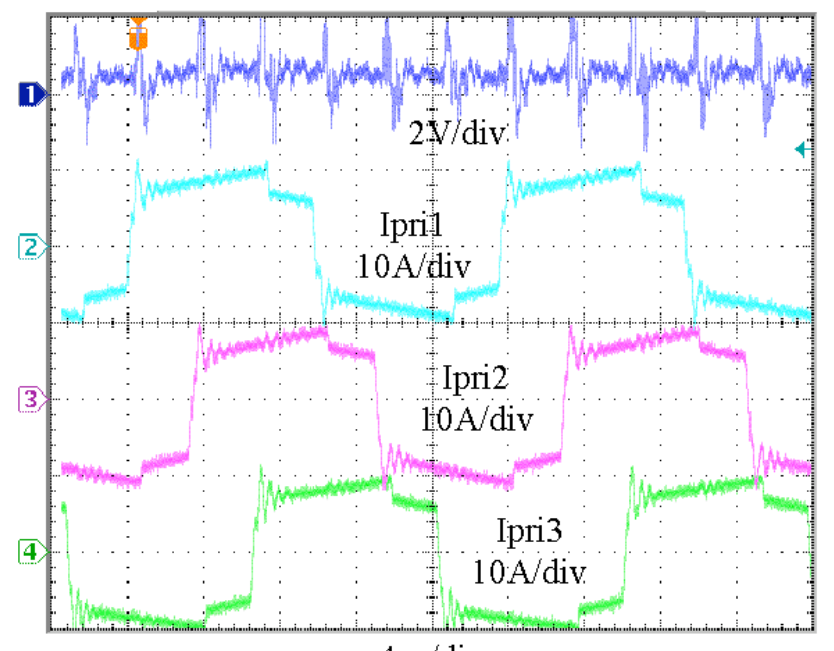

$4 \mu \mathrm{s} / \mathrm{div}$

(b)

Figure 9. Waveforms of (a) synchronized and (b) staggered power modules 
Phase staggering was implemented in the $3 \mathrm{~kW}$ discharge supply. It required some additional digital logic and a 4.9 $\mathrm{MHz}$ crystal oscillator. The master clock was fast enough to generate the narrow sync pulse required by the PWM controller and to provide sufficient timing accuracy. Scaling the circuit for additional modules would require changing the oscillator speed and additional timers or decoders depending on the total number of modules.

The effect of phase staggering is graphically shown in Figure 9. It shows the output voltage ripple of the $3 \mathrm{~kW}$ discharge supply and the primary current of the three modules when their phases are synchronized and staggered. The output voltage ripple was approximately $2.4 \mathrm{~V}$ peak-to-peak for the synchronized case and $0.8 \mathrm{~V}$ for the staggered case. This equates to a 67 percent reduction in output voltage ripple. This reduction in ripple can be used to reduce the size of filter components.

\section{Thruster Integration Testing}

Thruster integration tests were conducted using a $3 \mathrm{~kW}$-class, laboratory model NASA-120M HET. This thruster was developed several years ago by the NASA GRC Hall thruster program to serve as a test-bed for erosion diagnostics, capacitive discharge operation studies, and for investigation of the influence of channel parameters on operation. The thruster is depicted in Figure 9a.

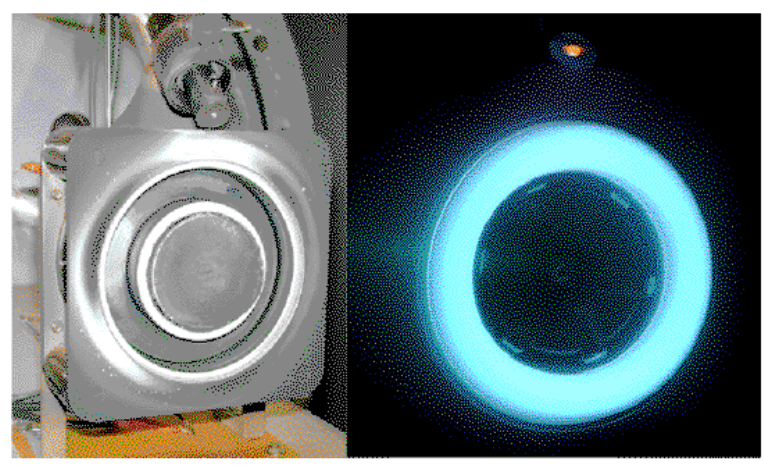

(a)

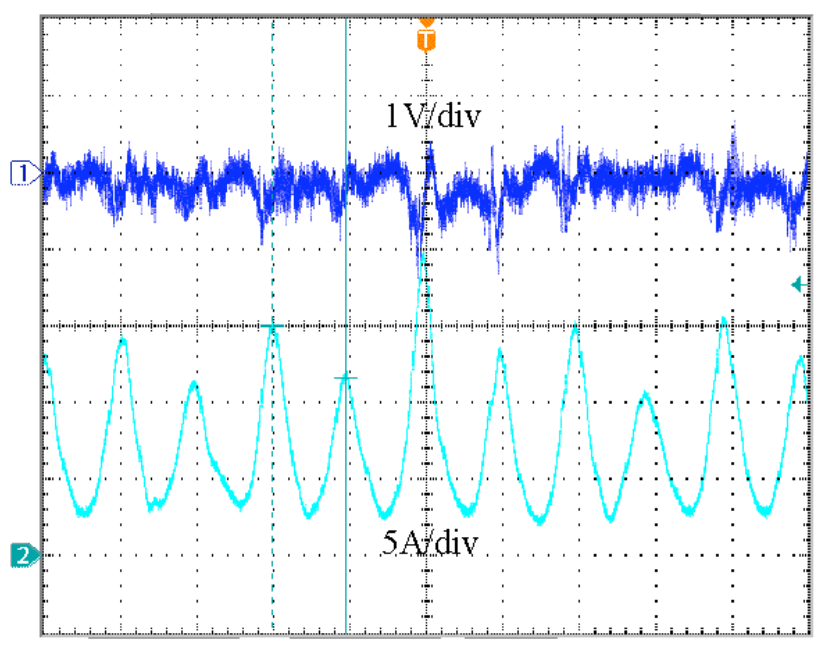

$40 \mu \mathrm{s} / \mathrm{div}$

(b)

Figure 10. (a) NASA-120Mv2 Hall effect thruster, (b) voltage and current oscillations

In general, HETs exhibit characteristic discharge current oscillations during operation. These are caused be inherent instabilities that occur during HET operation. ${ }^{15}$ These oscillations have a fundamental frequency in the range of $10^{4} \mathrm{~Hz}$ but also have components in the $10^{6} \mathrm{~Hz}$ range.

Figure $10 \mathrm{~b}$ shows discharge voltage and current oscillations of the NASA-120M thruster operating at $300 \mathrm{~V}$ and 7.0 A. For this test, a laboratory power supply and a $100 \mu \mathrm{F}$ capacitor between the anode and cathode were used. The current was measured downstream of the capacitor, directly into the thruster anode. As seen in the oscilloscope trace, the frequency of the oscillations was approximately $26 \mathrm{kHz}$ and the amplitude was in excess of $15.0 \mathrm{~A}$. Integration was conducted at these non-optimized conditions as it presented a tougher challenge for the discharge power supply.

Traditionally, a "matching network" consisting of an LC low pass filter has been used between the thruster and the discharge supply. This filter supplies the thruster the ripple current it requires for start-up and steady-state operation. Also, it attenuates current oscillations into the discharge supply that can cause control instabilities and lead to power supply failure. ${ }^{15-16}$ The matching network for the $3 \mathrm{~kW}$ discharge supply was implemented differently as shown above in Figure 6. Instead of one large bulk inductor, three smaller individual inductors were used on each output. This was done to avoid possible oscillations between the output filter capacitors in the modules due to interconnection in the experimental setup or thruster effects. The matching network used $28 \mu \mathrm{H}$ inductors and a 30 $\mu \mathrm{F}$ capacitor.

The test setup used the $3 \mathrm{~kW}$ discharge supply to operate the main discharge and a power console to supply power to the inner and outer magnets, cathode keeper and heater. Voltage and current data were obtained using 
digital multi-meters. A digital oscilloscope was used to record ripple and turn-on characteristics. Current measurements were taken at the output of the module in series with the matching network inductors. Voltage measurements were taken on the matching network capacitor.

Figure 11a shows the output voltage ripple of the $3 \mathrm{~kW}$ discharge supply and the individual module currents into the matching network. The operating conditions of the thruster were $300 \mathrm{~V}$ and $7.00 \mathrm{~A}$. The individual currents on the modules were 2.43, 2.34 and $2.23 \mathrm{~A}$. Thruster induced current oscillations of less than $0.50 \mathrm{~A}$ and voltage oscillations of approximately $1 \mathrm{~V}$ can be seen. However, the power supply still operated without problems. Turn-on transients are shown in Figure 11b. When the discharge voltage reached approximately $50 \mathrm{~V}$, the plasma was started and discharge current flowed. Since the thruster current ramped up, it took some time to charge output filter and matching network capacitors, so low voltage operation remained for some time. Once the current leveled, the discharge voltage rapidly ramped up causing instabilities in the discharge current. Finally, the discharge voltage and currents reached steady-state levels. Notice that the output currents from the individual modules were of equal magnitude throughout the transient period as demonstrated during resistive load tests.

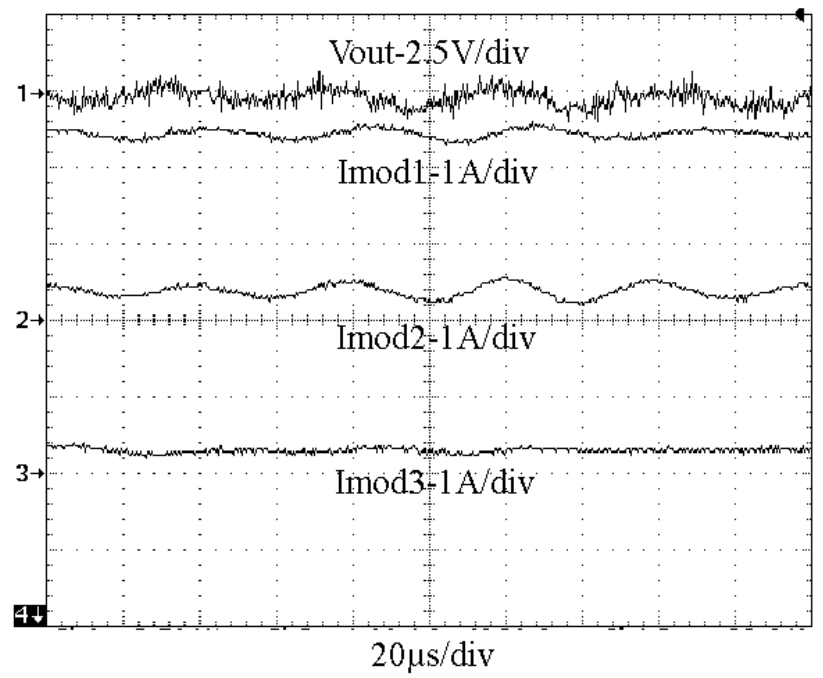

(a)

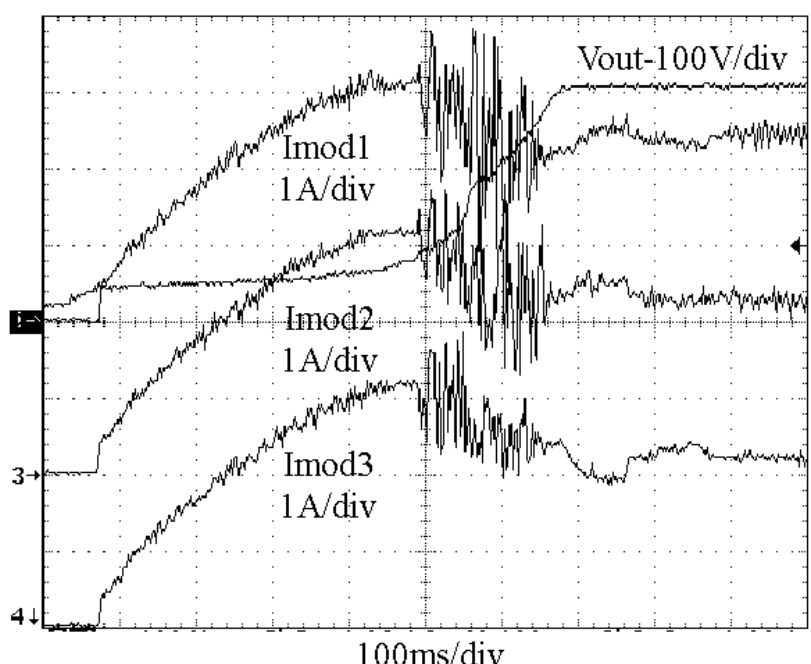

(b)

Figure 11. Waveforms of $3 \mathrm{~kW}$ power supply during thruster integration testing showing individual module currents during (a) steady state and (b) turn-on conditions

\section{Conclusions}

A $10 \mathrm{~kW}$ power module for HETs was designed and tested. This module successfully employed a $20 \mathrm{kHz}$ phase-shifted full-bridge converter that operated from a $100 \pm 20 \mathrm{~V}$ input and generated an output of $500 \mathrm{~V}$ and 20 A. Efficiencies from 94 to 96 percent were measured on a resistive load over a wide operational range. To turn this converter into a module a load current share and phase synchronization circuits were designed and tested using 1 $\mathrm{kW}$ modules on both resistive loads and the NASA-120v2 HET. Current sharing was better than 4.2 percent and was maintained even during turn-on conditions. The $10 \mathrm{~kW}$ power module and the current share and synchronization circuits will be integrated and developed into a building block for high power PPUs for thrusters like the NASA-457 HET.

\section{References}

${ }^{1}$ Gefert, L. P., et al., Options for the Human Exploration of Mars using Solar Electric Propulsion, AIP Conference Proceedings, No. 458, STAIF-99, November 1999, pp 1275-1280.

${ }^{2}$ Manzella, D., et al., "Laboratory Model $50 \mathrm{~kW}$ Hall Thruster," AIAA-2002-3676, 38th Joint Propulsion Conference, Indianapolis, Indiana, July 7-10, 2002.

${ }^{3}$ Hamley, J. A., et al. "Hall Thruster Direct Drive Demonstration." AIAA Paper 97-2787, 33rd Joint Propulsion Conference, Seattle, WA, 1997. 
${ }^{4}$ Jongeward, G. A., et al., "Development of a Direct Drive Hall Effect Thruster System," SAE Power Systems Conference, Paper No. 02PSC-77, Coral Springs, Florida, 29-31 October 2002.

${ }^{5}$ Hoskins, W. A., et al., "Direct Drive Hall Thruster System Development," AIAA-2003-4726, 39th Joint Propulsion Conference, Huntsville, Alabama, July 20-23, 2003.

${ }^{6}$ Schneider, T., et al., "High Voltage Solar Array Arc Testing for a Direct Drive Hall Effect Thruster System," 8th Spacecraft Charging Technology Conference, Huntsville, Alabama, October 20-24, 2003.

${ }^{7}$ Homiak, D., et al., "Direct Drive Hall Thruster (D2HT) System Test at AFRL Edwards AFB," AIAA-20044226, 40th Joint Propulsion Conference, Fort Lauderdale, Florida, July 11-14, 2004.

${ }^{8}$ Piñero, L. R., et al., "High Performance Power Module For Hall Effect Thrusters," AIAA-2002-3947, 38th Joint Propulsion Conference, Indianapolis, Indiana, July 7-10, 2002.

${ }^{9}$ Murphy, D. M., “The SCARLET Solar Array: Technology Validation and Flight Results," Deep Space 1 Technology Validation Symposium, Pasadena, California, 2000.

${ }^{10}$ Mason, L. S., "A Power Conversion Concept for the Jupiter Icy Moons Orbiter," AIAA-2003-6007, $1^{\text {st }}$ International Energy Conversion Engineering Conference, Portsmouth, Virginia, August 17-21, 2003.

${ }^{11}$ Jacobson, D. T., et al., "NASA's 2004 Hall Thruster Program," AIAA-2004-3600, 40th Joint Propulsion Conference, Fort Lauderdale, Florida, July 11-14, 2004.

${ }^{12}$ Hofer, R., et al, “A High Specific Impulse Two-Stage Hall Thruster with Plasma Lens Focusing”, IEPC-01036, 27th International Electric Propulsion Conference Proceedings, Pasadena, California, October 15-19, 2001.

${ }^{13}$ Korman, C., et at., "High Density, High Performance Modular DC-DC Power Converter," SAE Paper No. 200201-3260.

${ }^{14}$ Balogh, L., "Paralleling Power - Choosing and Applying the Best Technique for Load Sharing," SEM1500, Texas Instruments, 2002 Power Supply Design Seminar Manual.

${ }^{15}$ Hruby, V., et al., "DC-DC Converter for Hall Thruster Plasma Discharge", IEPC-99-061, 26th International Electric Propulsion Conference, Kitakyushu, Japan, October 1999.

${ }^{16}$ Randolph, T., et al., "The Mitigation of Discharge Oscillations in the Stationary Plasma Thruster", AIAA-942857, 30th Joint Propulsion Conference, June 27-29, 1994. 


\begin{tabular}{|c|c|c|c|}
\hline \multicolumn{3}{|c|}{ REPORT DOCUMENTATION PAGE } & $\begin{array}{l}\text { Form Approved } \\
\text { OMB No. 0704-0188 }\end{array}$ \\
\hline \multicolumn{4}{|c|}{ 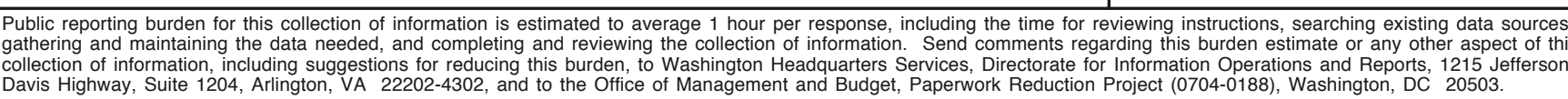 } \\
\hline 1. AGENCY USE ONLY (Leave blank) & $\begin{array}{r}\text { 2. REPORT DATE } \\
\text { March } 2005\end{array}$ & 3.1 & $\begin{array}{l}\text { ID DATES COVERED } \\
\text { echnical Memorandum }\end{array}$ \\
\hline $\begin{array}{l}\text { 4. TITLE AND SUBTITLE } \\
\text { Multi-Kilowatt Power Modu }\end{array}$ & or High-Power Hall Th & & 5. FUNDING NUMBERS \\
\hline $\begin{array}{l}\text { 6. AUTHOR(S) } \\
\text { Luis R. Piñero and Glen E. B }\end{array}$ & & & WBS-22-319-20-F2 \\
\hline \multicolumn{3}{|c|}{$\begin{array}{l}\text { 7. PERFORMING ORGANIZATION NAME(S) AND ADDRESS(ES) } \\
\text { National Aeronautics and Space Administration } \\
\text { John H. Glenn Research Center at Lewis Field } \\
\text { Cleveland, Ohio } 44135-3191\end{array}$} & $\begin{array}{l}\text { 8. PERFORMING ORGANIZATION } \\
\text { REPORT NUMBER } \\
\text { E-14816 }\end{array}$ \\
\hline \multicolumn{3}{|c|}{$\begin{array}{l}\text { 9. SPONSORING/MONITORING AGENCY NAME(S) AND ADDRESS(ES) } \\
\text { National Aeronautics and Space Administration } \\
\text { Washington, DC } 20546-0001\end{array}$} & $\begin{array}{l}\text { 10. SPONSORING/MONITORING } \\
\text { AGENCY REPORT NUMBER } \\
\\
\text { NASA TM-2005-213348 } \\
\text { AIAA-2004-3973 }\end{array}$ \\
\hline
\end{tabular}

Prepared for the 40th Joint Propulsion Conference and Exhibit cosponsored by the AIAA, ASME, SAE, and ASEE, Fort Lauderdale, Florida, July 11-14, 2004. Luis R. Piñero, NASA Glenn Research Center; and Glen E. Bowers, Akima Corporation, Fairview Park, Ohio 44126. Responsible person, Luis R. Piñero, organization code RPP, 216-977-7428.

12a. DISTRIBUTION/AVAILABILITY STATEMENT

12b. DISTRIBUTION CODE

Unclassified - Unlimited

Subject Categories: 20 and 33

Distribution: Nonstandard

Available electronically at http://gltrs.grc.nasa.gov

This publication is available from the NASA Center for AeroSpace Information, 301-621-0390.

13. ABSTRACT (Maximum 200 words)

Future NASA missions will require high-performance electric propulsion systems. Hall thrusters are being developed at NASA Glenn for high-power, high-specific impulse operation. These thrusters operate at power levels up to $50 \mathrm{~kW}$ of power and discharge voltages in excess of $600 \mathrm{~V}$. A parallel effort is being conducted to develop power electronics for these thrusters that push the technology beyond the $5 \mathrm{~kW}$ state-of-the-art power level. A $10 \mathrm{~kW}$ power module was designed to produce an output of $500 \mathrm{~V}$ and $20 \mathrm{~A}$ from a nominal $100 \mathrm{~V}$ input. Resistive load tests revealed efficiencies in excess of 96 percent. Load current share and phase synchronization circuits were designed and tested that will allow connecting multiple modules in parallel to process higher power.

\begin{tabular}{|c|c|c|c|}
\hline \multicolumn{2}{|l|}{ 14. SUBJECT TERMS } & & $\begin{array}{c}\text { 15. NUMBER OF PAGES } \\
15\end{array}$ \\
\hline
\end{tabular}



